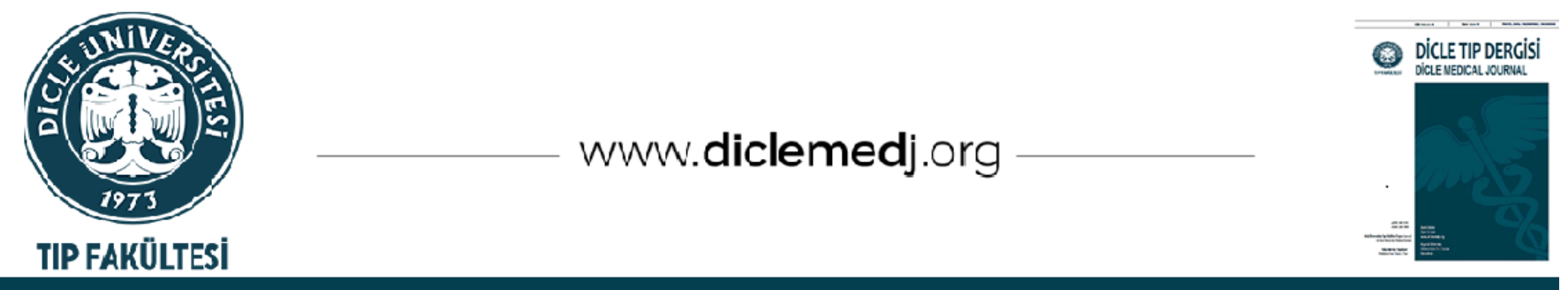

Original Article / Özgün Araştırma

\title{
Effects of Rhodiola rosea on indomethacin-induced gastric injury
}

\author{
Irmak Ferah Okkay ${ }^{D} 1_{1}$ ufuk Okkay ${ }^{D_{2}}$, Ozhan Karatas ${ }^{3}$ \\ 1 Department of Pharmacology, Faculty of Pharmacy, Ataturk University, Turkey \\ 2 Department of Medical Pharmacology, Faculty of Medicine, Ataturk University, Turkey \\ 3 Department of Pathology, Faculty of Veterinary Medicine, Sivas Cumhuriyet University, Turkey
}

Received: 10.07.2021; Revised: 13.10.2021; Accepted: 26.10.2021

\begin{abstract}
Objective: The objective of the present study was to evaluate the effects of Rhodiola rosea in the indomethacin-induced ulcer model in rats and to clarify the underlying mechanisms of action.

Methods: Rats in treatment groups were treated with Rhodiola rosea (RR) 14 days. Peptic ulcer was induced by indomethacin (IND) injection (100 mg/kg, p.o.). The groups $(\mathrm{n}=6)$ were designed as; Group I (control); Group II (IND): After $24 \mathrm{~h}$ of food starvation, rats were given only $100 \mathrm{mg} / \mathrm{kg}$ IND by oral gavage to induce gastric mucosal injury. Group III (ESO): Rats were pretreated with $20 \mathrm{mg} / \mathrm{kg}$ of ESO for 14 consecutive days by oral gavage. Group IV (RR): Rats were pretreated with $500 \mathrm{mg} / \mathrm{kg}$ RR for 14 consecutive days with oral gavage.

Results: Rhodiola rosea effectively alleviated indomethacin-induced ulcer via reduction in oxidative stress (decreased MDA and increased SOD, and GSH). Moreover, Rhodiola rosea alleviated indomethacin-induced damage by regulating expressions of COX enzymes, prostaglandin E2, proliferating cell nuclear antigen (PCNA), cell proliferation, apoptosis and regulated the NF- $\kappa B$ signaling pathway. Rhodiola rosea also attenuated inflammatory injury by suppressing TNF- $\alpha$, IL$1 \beta$, and NF- $\kappa \mathrm{B}$. The caspase-3 expression was also down-regulated in stomach tissues.

Conclusions: In conclusion, Rhodiola rosea protected the gastric mucosa from harmful effects of indomethacin and as a natural medicinal herb, Rhodiola rosea might be a potential therapeutic agent for preventing and treating indomethacininduced gastric damage.
\end{abstract}

Keywords: Rhodiola rosea, indomethacin, oxidative stress, inflammation, peptic ulcer.

DOI: 10.5798/dicletip.1037590

Correspondence / Yazışma Adresi: Irmak Ferah Okkay, Department of Pharmacology, Faculty of Pharmacy, Ataturk University, 25100 Erzurum, Turkey e-mail: irmakferah@atauni.edu.tr 


\section{İndometazin ile indüklenen mide hasarı üzerine Rhodiola rosea'nın etkileri}

Öz

Amaç: Bu çalışmada, sıçanlarda indometazin ile indüklenen ülser modelinde Rhodiola rosea'nın etkilerini değerlendirmek ve etki mekanizmalarını aydınlatmak amaçlanmıştır.

Yöntemler: Sıçanlar dört gruba ayrılacak şekilde tasarlandı. Tedavi gruplarındaki sıçanlar 14 gün Rhodiola rosea (RR) ile tedavi edildi. Peptik ülser, indometasin (IND) enjeksiyonu (100 mg/kg, p.o.) ile indüklendi. Grup dizaynı ( $\mathrm{n=6}$ ); Grup I (kontrol); Grup II (IND): 24 saatlik açlıktan sonra, sıçanlara gastrik mukozal hasarı indüklemek için oral gavaj yoluyla sadece $100 \mathrm{mg} / \mathrm{kg}$ IND verildi. Grup III (ESO): Sıçanlara, ardışı 14 gün boyunca oral gavaj yoluyla 20 mg/kg ESO ile ön-tedavi uygulandı. Grup IV (RR): Sıçanlara, oral gavaj ile art arda 14 gün boyunca $500 \mathrm{mg} / \mathrm{kg}$ RR ile ön-tedavi uygulandı.

Bulgular: Rhodiola rosea, indometazin bağlı olarak gelişen ülserde oksidatif stresi (MDA seviyesini azaltıp SOD ve GSH aktivitesini artırarak) azalttı. Ayrıca, Rhodiola rosea, COX enzimleri, prostaglandin E2, prolifere hücre çekirdek antijeni (PCNA), hücre proliferasyonu ve apoptoz ekspresyonlarını düzenleyerek indometazin kaynaklı hasarı azalttı ve ayrıca NF-kB sinyal yolunu regüle etti. Rhodiola rosea ayrıca TNF- $\alpha$, IL-1 $\beta$ ve NF-KB'yi baskılayarak inflamatuvar hasarı hafifletti. Rhodiola rosea tedavisi ile Kaspaz-3 ekspresyonunun da mide dokularında azaldığı tespit edildi.

Sonuç: Sonuç olarak, Rhodiola rosea mide mukozasını indometazinin zararlı etkilerinden korumuştur ve doğal bir tıbbi bitki olarak Rhodiola rosea, indometazin kaynaklı mide hasarını önlemek ve tedavi etmek için potansiyel bir terapötik ajan olabilir.

Anahtar kelimeler: Rhodiola rosea, indometazin, oksidatif stres, inflamasyon, peptik ülser.

\section{INTRODUCTION}

In the pathophysiology of ulcer, an imbalance between protective and aggressive factors such as pepsin/hydrochloric acid secretion, mucosal hypoperfusion, free radicals and oxidants, as well as exogenous factors such as alcohol/caffeine intake and certain types of drugs such as NSAIDS plays an important role ${ }^{1}$. Pathologically, gastric ulcer can occur when aggressive factors overwhelm protective mechanisms. NSAIDs, which are considered among exogenous aggressive factors, are widely prescribed, and continuous administration of these drugs can cause serious side effects ranging from gastric mucosal erosions to gastric bleeding. NSAIDs destroy the natural defense by disrupting the balance between protective and aggressive factors in ulcer pathogenesis ${ }^{2}$.Various treatment modalities such as antacids, proton pump inhibitors and histamine type 2 receptor blockers are widely prescribed in the treatment of ulcer ${ }^{3}$. It has been shown that the effects of histamine type 2 receptor blockers weaken over time. Moreover, the usage of proton pump inhibitors is limited due to their side effects such as osteoporotic fracture, vitamin B12/magnesium/iron deficiencies, anemia and dementia ${ }^{4,5}$. Correction of the imbalance between aggressive and protective factors in the gastrointestinal mucosa is the basis of ulcer treatment. In this context, anti-inflammatory and antioxidant agents that can maintain this balance become popular.

Rhodiola rosea (RR) belongs to Crassulaceae family which is mainly distributed mostly in Europe, North America, and Asia. RR is a traditional medicinal herb which has been used in traditional folk medicine since ancient times ${ }^{6}$. Therapeutic properties of RR are related to flavonoids, phenylpropanoids, and organic acids in its roots and rhizomes. RR has also numerous beneficial pharmacological activities including anti-inflammatory, antioxidant, antidepressive, antifibrotic, antiallergic, anticancer and antiapoptotic activities ${ }^{7-11}$. This is the first study to investigate the protective effects of RR in peptic ulcer disease. 
We planned this study based on the idea that RR can be applied as an effective agent in ulcer caused by the use of NSAIDs, based on its high antioxidant and anti-inflammatory properties.

\section{METHODS}

\section{Chemicals}

RR was purchased from Herb Pharm (Oregon, USA) as hydroalcoholic extract prepared by treating the dried root of the plant with a solvent $(52-62 \%$ organic cane alcohol) in the ratio of 1:5. Indomethacin (IND) was purchased from Deva Pharmaceutical Company-Turkey and ESO was obtained from AstraZeneca Pharmaceutical Company-Turkey.

\section{Animals}

Twenty-four male Wistar rats $(240-310 \mathrm{~g})$ were obtained from Ataturk University Experimental Research and Application Center. Rats were kept in standard cages (normal light/dark cycle) at constant temperature $\left(23 \pm 1{ }^{\circ} \mathrm{C}\right)$. All experiments were approved by the Ethic Council of Ataturk University, Turkey (No: E.2100036538).

\section{Experimental design}

The groups ( $\mathrm{n}=6)$ were designed as; Group I (control); Group II (IND): After 24h of food starvation, rats were given only $100 \mathrm{mg} / \mathrm{kg}$ IND by oral gavage to induce gastric mucosal injury ${ }^{12}$. Group III (ESO): Rats were pretreated with $20 \mathrm{mg} / \mathrm{kg}$ of ESO for 14 consecutive days by oral gavage. Rats were refrained from eating for one day prior to the last day of treatment and then they were treated with IND $(100 \mathrm{mg} / \mathrm{kg}$, p.o.) to induce ulcer. Group IV (RR): Rats were pretreated with $500 \mathrm{mg} / \mathrm{kg}$ RR for 14 consecutive days with oral gavage ${ }^{13,14}$. Rats were refrained from eating for one day prior to the last day of treatment and then they were given IND (100 mg/kg, p.o.) to induce ulcer. Four hours after IND administration, all rats were sacrificed by administrating high dose of
(50 mg/kg) anesthesia with sodium-thiopental (Pental $\mathbb{R}$ IE Ulagay-Turkey) intraperitoneally. Rats' stomachs were excised out and afterward, each stomach tissue was cut into pieces. $10 \%$ formalin solution was used for sample fixation for immunohistochemical and histopathological analysis. The remaining tissues were kept at $86^{\circ} \mathrm{C}$ for biochemical analysis and were kept in RNALater $®$ (Thermo Fisher Scientific, Carlsbad, CA, USA) stabilization reagent for molecular analysis.

\section{Biochemical analysis}

Stomach tissues were powdered in sample tubes with liquid nitrogen and in Tissuelyser II (Qiagen-Germany). Then, we homogenized approximately $50 \mathrm{mg}$ tissue in $1 \mathrm{~mL}$ homogenate buffer solution and centrifuged for $5 \mathrm{~min}$ at $5000 \times \mathrm{g}$.

The levels of malondialdehyde (MDA), and the activities of superoxide dismutase (SOD), catalase (CAT) and glutathione (GSH) were measured by ELISA kit (Elabscience, United States) in accordance with kit instructions as previously described ${ }^{15}$. The absorbance measurement was conducted at $450 \mathrm{~nm}$ with spectrophotometer.

\section{Molecular Analysis}

mRNA extraction and cDNA synthesis were carried out as previously described with RNeasy easy kit (Qiagen, Hilden, Germany) ${ }^{16}$. Real-time RT-PCR analysis also were performed as previously described. Stomach tissue relative mRNA NF- $\mathrm{kB}$, tumor necrosis factor alpha (TNF- $\alpha$ ) and interleukin 1 beta (IL-1 $\beta$ ) expression levels were determined by RotorGene $\mathrm{Q}$ (QIAGEN). $\beta$-actin was utilized as the reference gene. The target gene expression levels were compared with the housekeeping gene $\beta$-actin. The PCR primers are listed in Table 1. 
Table I: Primers sequence list used for RT-PCR.

\begin{tabular}{|c|c|c|}
\hline Genes & Forward Sequence $\left(5^{\prime}-3^{\prime}\right)$ & Reverse Sequence $\left(3^{\prime}-5^{\prime}\right)$ \\
\hline$T N F-\alpha$ & CACACGAGACGCTGAAGTAG & AACAGTCTGGGAAGCTCTGA \\
\hline$I L-1 \beta$ & TGCTGTGTGATTGCAGACAA & GTACAGCGTTCCCAGTCATC \\
\hline$N F-\kappa B$ & CGAATGTAGACACGAAGCGT & CAACCAGGAAGCATAGACCG \\
\hline
\end{tabular}

\section{Histopathological analysis}

Histopathological analyses were performed as previously described ${ }^{16}$. For histopathological assessment, sections were stained with hematoxylin and eosin (H\&E). The histopathological lesion scores were evaluated according to the method of Liu et al ${ }^{17}$.

\section{Immunohistochemical analysis}

Immunohistochemical analyses were performed as previously described ${ }^{16}$. Sections were examined with light microscope (Leica:DM-1000). Immunoreactivity was evaluated using a semi quantitative 4-grade scale (0: no reaction; 1 : weak; 2: mild; 3 : moderate; 4: strong immunoreactivity).

\section{Statistical analysis}

The data was stated as the mean \pm standard deviation. Elisa and RT-PCR results were subjected to one-way analysis of variance (ANOVA) followed by post hoc Tukey's Test with the SPSS STATISTIC (V-23) software $(\mathrm{p}<0.05)$.For histopathological and immunohistochemical evaluations, analyzes were conducted with Kruskal Wallis test followed by post hoc Mann-Whitney U test ( $\mathrm{p}<$ $0.05)$.

\section{RESULTS}

\section{Biochemical results}

\section{Oxidative stress markers}

SOD, CAT and GSH activity were significantly declined while MDA levels were significantly elevated in the IND group in comparison to control group. The SOD, CAT and GSH activity increased whereas MDA levels decreased significantly in RR and ESO groups as compared to IND group (Fig. 1).
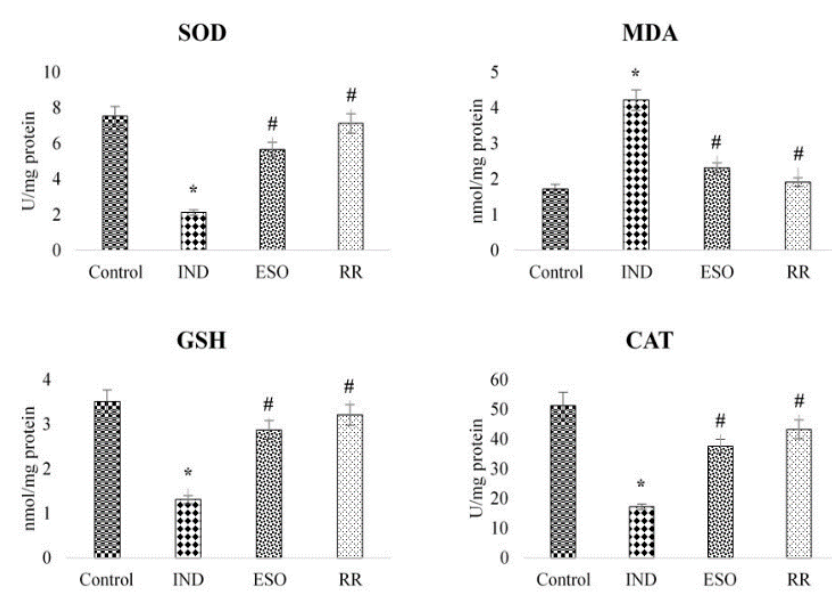

Fig. 1. Effects of RR on oxidative stress markers in gastric tissue. Data are presented as mean $\pm \mathrm{SD}^{*} \mathrm{p}<0.001$ vs. control group, \# $\mathrm{p}<0.001$ vs. IND group. IND: Indomethacin, ESO: Esomeprazole, RR: Rhodiola rosea

\section{Molecular results}

TNF- $\alpha, N F-\kappa B$ and IL-1 $\beta$ expressions were significantly increased in the IND group in comparison to control group. The mRNA expression levels of TNF- $\alpha, N F-\kappa B$ and IL- $1 \beta$ mRNA showed a decrease in the RR and ESO group when compared to the IND group (Fig.2).

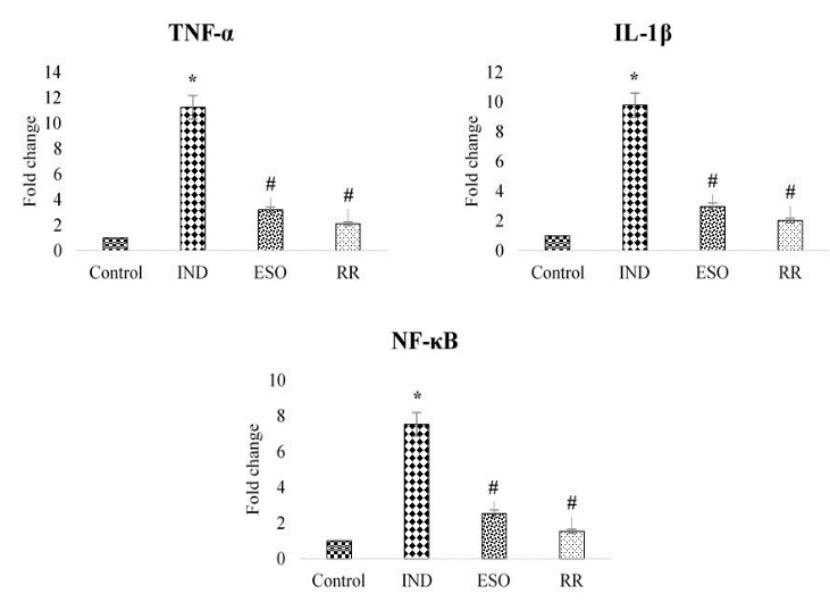

Fig. 2. Relative mRNA expression levels of TNF- $\alpha$, IL-1 $\beta$ and NF- $\kappa \mathrm{B}$ in the gastric tissue. Data are presented as mean $\pm S D * p<0.001$ vs. control group, $\# p<0.001$ vs. IND group. IND: Indomethacin, ESO: Esomeprazole, RR: Rhodiola rosea 


\section{Histopathological results}

The control group exhibited normal structure while IND group demonstrated severe pathological alterations with damaged lamina epithelialis and hemorrhagic damage. Pretreatment with RR showed normal mucosa with minimal inflammatory cells infiltrations with mild histopathological changes.There was no superficial mucosal ulceration and fewer inflammatory cellular infiltrates in RR group. According to our histopathological score results, IND caused marked increase in gastric mucosal injury, leukocyte infiltration and gastric hemorrhage. Significant reduce was observed in the both ESO and RR group when compared to IND group (Fig.3).

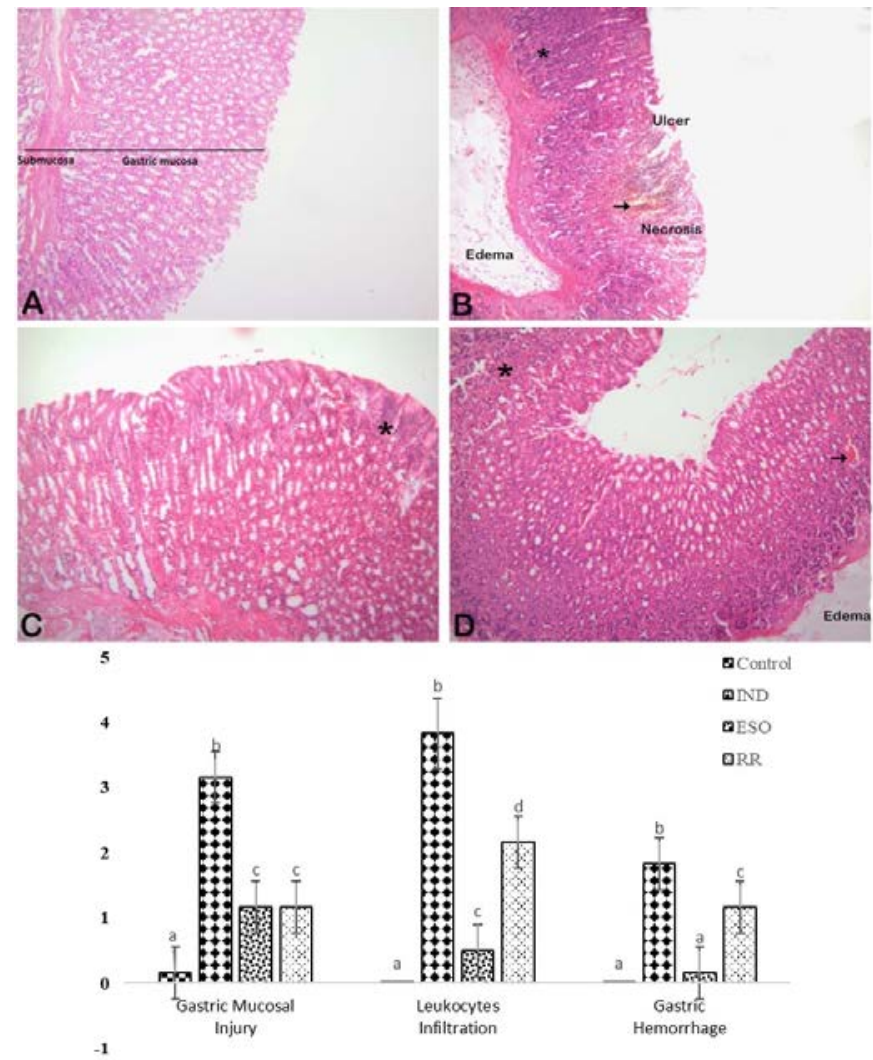

Fig. 3. Histopathological analysis of gastric sections. (H\&E, x100). (A) Control group; (B) IND group; (C) ESO group; (D) RR group. * Leukocyte infiltration, $>$ Necrosis. (E) Histopathological scores. Data are presented as mean \pm SD; a,b,c,d Differences between the groups $(\mathrm{p}<0.05)$. IND: Indomethacin, ESO: Esomeprazole, RR: Rhodiola rosea

\section{Immunohistochemical results}

We evaluated COX-1, COX-2, PGE2, Caspase-3 and PCNA immunoreactivity in the stomach sections (Fig. 4-8). Caspase-3 expression was up-regulated significantly in IND group in comparison with control group while RR and ESO groups showed significant decrease in Caspase-3 expression. Immunoreactivity of COX-1, COX-2, PGE2 and PCNA in the stomach were lower in IND group in comparison with the control group, while these parameters were significantly higher in both ESO and RR groups.

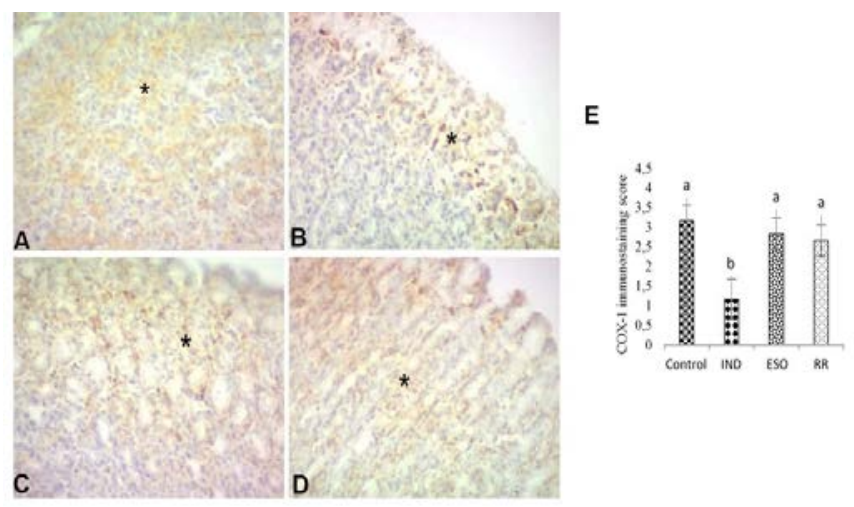

Fig. 4.Immunohistochemical analysis of COX-1 in gastric tissue (x400). (A) Control group (B) IND group (C) ESO group; (D) RR group. (E) Immunohistochemistry scoring for COX-1. Data are presented as mean \pm SD; a,b Differences between the groups $(p<0.05)$. IND: Indomethacin, ESO: Esomeprazole, RR: Rhodiola rosea

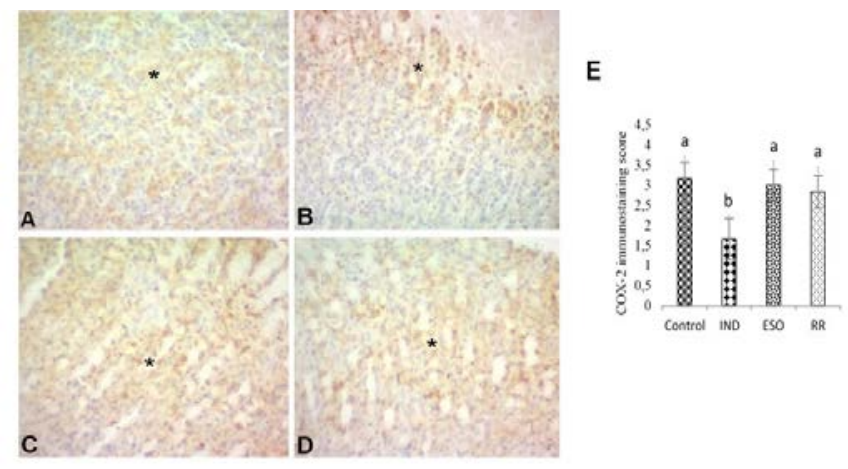

Fig. 5. Immunohistochemical analysis of COX-2 in gastric tissue (x400). (A) Control group (B) IND group (C) ESO group; (D) RR group. (E) Immunohistochemistry scoring for COX-2. Data are presented as mean \pm SD; a,b Differences between the groups $(p<0.05)$. IND: Indomethacin, ESO: Esomeprazole, RR: Rhodiola rosea 


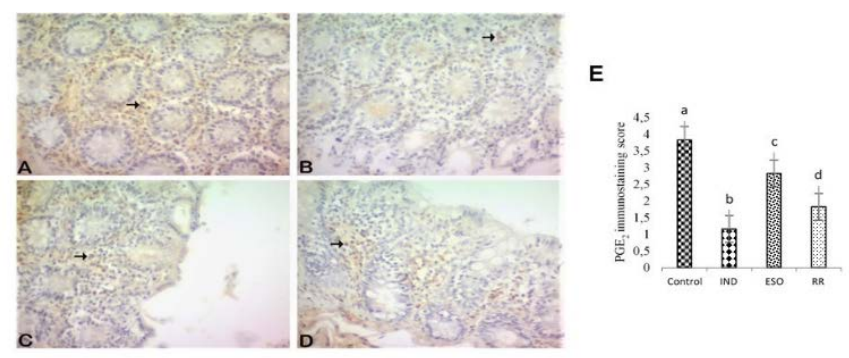

Fig. 6. Immunohistochemical analysis of PGE2 in gastric tissue (x400). (A) Control group (B) IND group (C) ESO group; (D) RR group. (E) Immunohistochemistry scoring for PGE2. Data are presented as mean \pm SD; a,b,c,d Differences between the groups $(p<0.05)$. IND: Indomethacin, ESO: Esomeprazole, RR: Rhodiola rosea

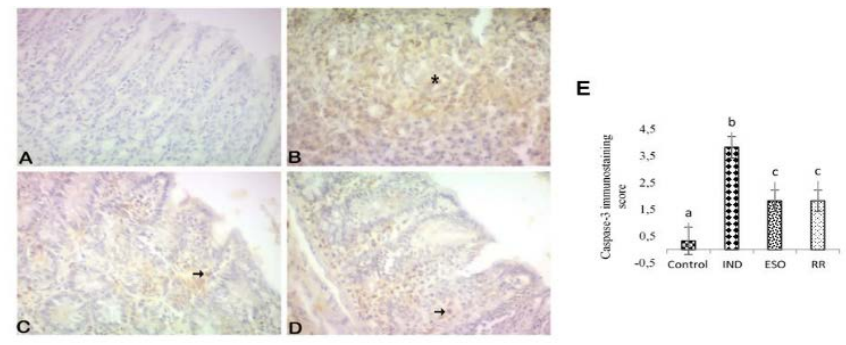

Fig. 7. Immunohistochemical analysis of Caspase-3 in gastric tissue (x400). (A) Control group (B) IND group (C) ESO group; (D) RR group. (E) Immunohistochemistry scoring for Caspase-3. D Data are presented as mean \pm SD; $a, b, c$ Differences between the groups $(p<0.05)$. IND: Indomethacin, ESO: Esomeprazole, RR: Rhodiola rosea

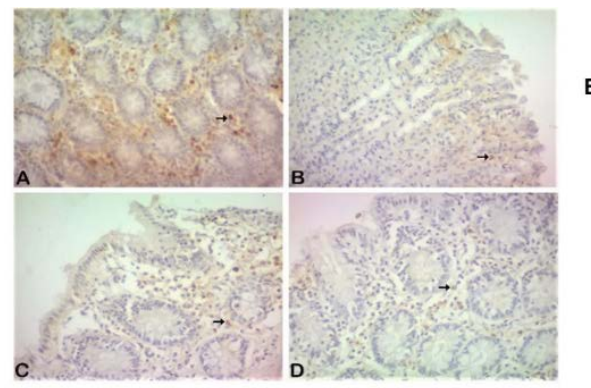

E

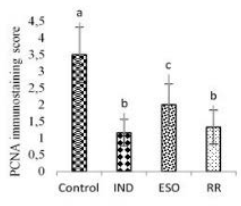

Fig. 8. Immunohistochemical analysis of PCNA in gastric tissue (x400). (A) Control group (B) IND group (C) ESO group; (D) RR group. (E) Immunohistochemistry scoring for PCNA. Data are presented as mean \pm SD; a,b,c Differences between the groups $(p<0.05)$. IND: Indomethacin, ESO: Esomeprazole, RR: Rhodiola rosea

\section{DISCUSSION}

This study has been designed to evaluate the effects of RR in NSAID-related ulcer and to examine the effects of RR towards inflammation, oxidative stress, and also cell turnover biomarkers, which all have an important role in the gastric ulcer healing.

One of the important mechanisms in the formation of ulcers caused by NSAIDs is the COX inhibition due to NSAIDs and the consequent decrease in PG production ${ }^{18}$. It is known that INDinduced stomach damage is caused by the decrease in PGE2 level, which increases mucus production and repairs the gastric mucosa. According to our immunohistochemical results, expressions of COX-1, COX-2 and PGE2 levels in the RR and ESO groups were significantly increased in comparison to IND group. In a previous study it was showed that ESO increased the COX levels in line with our results ${ }^{19}$. COX-1 and COX-2 levels were similar in both RR and ESO groups but PGE2 levels were higher improved in the ESO group than RR group. It was obvious that $R R$ reversed the COX inhibition because of NSAIDs and preserved the gastric mucosa like ESO.

NSAIDs have been shown to be involved in oxidative stress, which results in generation of ROS and elevation of MDA with decreased SOD, CAT and GSH activity which are important fighters of the intracellular antioxidant defense system ${ }^{20}$. In previous reports, the role of oxidative stress in NSAID-induced gastric damage has been extensively investigated. Its capability to decrease MDA increase GSH and SOD activities confirms its antioxidant effect against NSAID-induced oxidative stress. In a previous study in gastric ulcer formed rats, ESO has been reported to reduce oxidative stress, consistent with our results ${ }^{19}$. Findings of our study were in line with Cui et al., who revealed that RR inhibited oxidative stress against carbon tetrachloride-induced hepatotoxicity ${ }^{21}$. There was no difference between ESO and RR in terms of reducing oxidative stress.

There is a widely accepted relationship between inflammation and NSAID-associated stomach ulcers. NSAIDs exacerbate gastric injury by triggering neutrophil infiltration into the gastric mucosa through the induction of inflammatory responses. In addition to the widely accepted 
relationship between inflammation and NSAIDinduced gastric ulcers, oxidative stress also leads to the activation of proinflammatory cytokines that play an active role in ulceration. Proinflammatory cytokines like TNF- $\alpha$ and IL-1 $\beta$ are the key mediators of the gastric injury ${ }^{22-25}$. One of the target molecules in gastric injury is NF$\kappa \mathrm{B}$, which is an important transcription factor and induces many inflammatory cytokines ${ }^{26,27}$. With the increase of NF- $\kappa \mathrm{B}$, the inflammatory pathway becomes stronger by triggering the release of other proinflammatory mediators, thus exacerbating stomach damage ${ }^{28}$. TNF- $\alpha$, IL- $1 \beta$ and $\mathrm{NF}-\kappa \mathrm{B}$ in gastric tissues were significantly higher in IND given rats, while RR and ESO treatment reduced the overexpression of these inflammatory parameters. Our results showed that the protective effect of RR in peptic ulcer may be correlated with its anti-inflammatory and antioxidative effects. Additionally, cell proliferation takes a part in the healing of peptic ulcers, and it is known that PCNA is associated with cellular DNA synthesis as a marker of cell proliferation ${ }^{29}$. In addition, NSAID administration has previously been shown to result in an increase in apoptosis via caspase-3-dependent pathways and cause high expression of caspase-3, a marker of apoptotic cell death ${ }^{30}$. In this study, it was shown that PCNA expression decreased and caspase-3 expression increased as a result of the destructive effects of IND. In previous studies in the field of gastric ulcer, in parallel with the results of our study, it was shown that ESO increased the PCNA level while decreasing the level of caspase-319. It was also observed that RR increased the PCNA expression while inhibiting caspase-3. While there was no difference between ESO and RR groups in terms of Caspase-3 levels, it was observed that the curative effect of ESO was more pronounced than RR group in terms of PCNA levels. The tissue damage was also confirmed by our histopathological results. Deterioration of the lamina epithelium with gastric gland necrosis were observed in IND group and a significant improvement was observed in the ESO and RR group.
The current study revealed that the RR had gastroprotective effects against IND-induced ulcer and also RR protected the gastric mucosa from the harmful effects of IND through antioxidant, anti-inflammatory and antiapoptotic effects.

Ethics Committee Approval: All experiments were approved by the Ethic Council of Ataturk University, Turkey (No: E.2100036538).

Declaration of Conflicting Interests: The authors declare that they have no conflict of interest.

Financial Disclosure: No financial support was received.

\section{REFERENCES}

1. Tytgat GN. Etiopathogenetic principles and peptic ulcer disease classification. Dig Dis. 2011; 29: 454-8.

2. Xiao X, Nakatsu G, Jin $Y$, et al. Gut Microbiota Mediates Protection Against Enteropathy Induced by Indomethacin. Sci Rep. 2017; 7: 40317.

3. McRorie JW, Kirby JA, Miner PB. Histamine2receptor antagonists: Rapid development of tachyphylaxis with repeat dosing. World J Gastrointest Pharmacol Ther. 2014; 5: 57-62.

4. Hammond DA, Kathe N, Shah A, et al. CostEffectiveness of Histamine2 Receptor Antagonists Versus Proton Pump Inhibitors for Stress Ulcer Prophylaxis in Critically Ill Patients. Pharmacotherapy. 2017; 37: 43-53.

5. Xavier S, Magalhaes J, Cotter J. Proton Pump Inhibitors: Are They a Real Threat to the Patient? GE Port J Gastroenterol. 2018; 25: 243-52.

6. Zhang K, Si XP, Huang J, et al. Preventive Effects of Rhodiola rosea L. on Bleomycin-Induced Pulmonary Fibrosis in Rats. Int J Mol Sci. 2016; 17.

7. Diaz Lanza AM, Abad Martinez MJ, Fernandez Matellano L, et al. Lignan and phenylpropanoid glycosides from Phillyrea latifolia and their in vitro anti-inflammatory activity. Planta Med. 2001; 67: 21923.

8. Qian EW, Ge DT, Kong SK. Salidroside protects human erythrocytes against hydrogen peroxideinduced apoptosis. J Nat Prod. 2012; 75: 531-7. 
9. van Diermen D, Marston A, Bravo J, et al. Monoamine oxidase inhibition by Rhodiola rosea L. roots. J Ethnopharmacol. 2009; 122: 397-401.

10. Chen AY, Chen YC. A review of the dietary flavonoid, kaempferol on human health and cancer chemoprevention. Food Chem. 2013; 138: 2099-107.

11. Zhu L, Wei T, Gao J, et al. The cardioprotective effect of salidroside against myocardial ischemia reperfusion injury in rats by inhibiting apoptosis and inflammation. Apoptosis. 2015; 20: 1433-43.

12. El-Ashmawy NE, Khedr EG, El-Bahrawy HA, et al. Nebivolol prevents indomethacin-induced gastric ulcer in rats. J Immunotoxicol. 2016; 13: 580-9.

13. Vasileva LV, Saracheva Kcapital Ie C, Ivanovska MV, et al. Beneficial Effect of Chronic Treatment with Extracts from Rhodiola Rosea L. and Curcuma Longa L. on the Immunoreactivity of Animals Subjected to a Chronic Mild Stress Model. Folia Med (Plovdiv). 2017; 59: 443-53.

14. Gryszczynska A, Mikolajczak PL, Grzadzielski P, et al. Comparison of Extracts from Root of Rhodiola Rosea and Rhodiola Kirilowii Inhibitory Action on Alcohol Tolerance Development in Rats. Alcohol and Alcoholism. 2015; 50.

15. Okkay U, Ferah Okkay I, Aydin IC, et al. Effects of Achillea millefolium on cisplatin induced ocular toxicity: an experimental study. Cutan Ocul Toxicol. 2021: 1-7.

16. Okkay U, Ferah Okkay I, Cicek B, et al. Achillea millefolium alleviates testicular damage in paclitaxelintoxicated rats via attenuation of testicular oxidoinflammatory stress and apoptotic responses. Andrologia. 2021: e14028.

17. Liu J, Wang F, Luo $\mathrm{H}$, et al. Protective effect of butyrate against ethanol-induced gastric ulcers in mice by promoting the anti-inflammatory, anti-oxidant and mucosal defense mechanisms. Int Immunopharmacol. 2016; 30: 179-87.

18. Gudis K, Sakamoto C. The role of cyclooxygenase in gastric mucosal protection. Dig Dis Sci. 2005; 50 Suppl 1: S16-23.

19. Fornai M, Colucci R, Antonioli L, et al. Effects of esomeprazole on healing of nonsteroidal antiinflammatory drug (NSAID)-induced gastric ulcers in the presence of a continued NSAID treatment: Characterization of molecular mechanisms. Pharmacol Res. 2011; 63: 59-67.
20. Zeytun H, Basuguy E, İBİLoĞLu İb, et al. Carvacrol'un Ratlarda Böbrek İskemi Reperüzyon Hasarı Üzerine Koruyucu Etkileri. Dicle Tıp Dergisi. 2020: 696-703.

21. Cui H, Liu X, Zhang J, et al. Rhodiola rosea L. Attenuates Cigarette Smoke and LipopolysaccharideInduced COPD in Rats via Inflammation Inhibition and Antioxidant and Antifibrosis Pathways. Evid Based Complement Alternat Med. 2021; 2021: 6103158.

22. Wassmann S, Stumpf $M$, Strehlow $K$, et al. Interleukin- 6 induces oxidative stress and endothelial dysfunction by overexpression of the angiotensin II type 1 receptor. Circ Res. 2004; 94: 534-41.

23. Eraslan E, Tanyeli A, Guler MC, et al. Agomelatine prevents indomethacin-induced gastric ulcer in rats. Pharmacol Rep. 2020; 72: 984-91.

24. Eraslan E, Tanyeli A, Guler MC, et al. Agomelatine prevents indomethacin-induced gastric ulcer in rats. Pharmacological Reports. 2020; 72: 984-91.

25. Wu JZ, Liu YH, Liang JL, et al. Protective role of betapatchoulene from Pogostemon cablin against indomethacin-induced gastric ulcer in rats: Involvement of anti-inflammation and angiogenesis. Phytomedicine. 2018; 39: 111-18.

26. Chang X, Luo F, Jiang W, et al. Protective activity of salidroside against ethanol-induced gastric ulcer via the MAPK/NF-kappaB pathway in vivo and in vitro. Int Immunopharmacol. 2015; 28: 604-15.

27. Jeong HY, Choi YS, Lee JK, et al. Anti-Inflammatory Activity of Citric Acid-Treated Wheat Germ Extract in Lipopolysaccharide-Stimulated Macrophages. Nutrients. 2017; 9.

28. Kunnumakkara AB, Sailo BL, Banik K, et al. Chronic diseases, inflammation, and spices: how are they linked? J Transl Med. 2018; 16: 14.

29. Leung AY, Leung JC, Chan LY, et al. Proliferating cell nuclear antigen (PCNA) as a proliferative marker during embryonic and adult zebrafish hematopoiesis. Histochem Cell Biol. 2005; 124: 105-11.

30. Fornai M, Colucci R, Antonioli L, et al. Effects of pantoprazole on ulcer healing delay associated with NSAID treatment. Naunyn Schmiedebergs Arch Pharmacol. 2009; 379: 305-13. 